\title{
КРАЕВЕДЧЕСКИЙ ПОДХОД В ФОРМИРОВАНИИ ПАТРИОТИЗМА
}

\author{
Максименко Ольга Александровна \\ МБОУ «Константиновская школа» \\ Симферопольского района
}

\begin{abstract}
Аннотация. Краеведческий подход позволяет учащимся наилучшим образом узнать родной край, свою «малую родину» как неотъемлемую составляющую часть Российского государства, получить представление о природных и культурных богатствах родного края, формирует любовь к своей местности, своей стране, закладывает основы патриотизма.

Ключевые слова: краеведение, «Крымоведение», Российская Федерация, родной край, патриотизм.
\end{abstract}

\section{LOCAL HISTORY APPROACH TO THE FORMATION OF PATRIOTISM}

\section{Maksimenko Olga Aleksandrovna}

\begin{abstract}
Local history approach allows students to find out their native land, their "small homeland" as an integral part of the Russian state in the best way,to get an idea of the natural and cultural wealth of their native land, form a love for their locality, their country, lays the foundation of patriotism.
\end{abstract}

Key words: local history, «Crimean Studies», Russian federation, native land, patriotism.

Без всестороннего комплексного изучения родного края невозможно формирование у человека культуры, гражданственности, патриотизма. Академик Д.С. Лихачев

Чтобы любить свою страну, надо изучать её. Ведь нам несказанно повезло - мы живем в удивительной стране. У нас красивейшие реки и озера, сказочные леса, величественные горы. Старинные города, в которых былинная Русь живет и поныне, а также стремительно растущие современные мегаполисы - всё это наше достояние, наша история, наше наследие.

У каждого человека есть врождённая тяга к познанию. Поэтому моя задача как учителя географии показать детям красоту природы и 
достопримечательности городов России, формировать интерес к изучению и исследованию родного края и воспитывать любовь к своей стране, чувство патриотизма, духовность, нравственность обучающихся. Краеведческий подход позволяет учащимся наилучшим образом узнать родной край, свою «малую родину» как неотъемлемую составляющую часть Российского государства, получить представление о природных и культурных богатствах родного края, формирует любовь к своей местности, своей стране, закладывает основы патриотизма [3, стр.10].

Знание своего края, его прошлого и настоящего необходимо для непосредственного участия в его преобразовании, поскольку родной край живая, деятельная частица великого мира. Краеведение рождает чувство патриотизма - глубокой любви к Родине.

Краеведческая работа в школе основывается на трех основных направлениях: изучение краеведческого материала на уроках, факультативных занятиях и во внеурочной деятельности путем поисковой и исследовательской работы.

Сегодня все больше регионов России создают новые программы и методические разработки, отвечающие давно назревшей потребности воспитывать с детства любовь к своей малой родине, отчему краю, району, селу. Краеведение является основным из приоритетных направлений деятельности МБОУ «Константиновская школа». С 2014 года в годовой план школ был включен курс «Крымоведение». Программа данного курса построена по концентрическому принципу и состоит из нескольких разделов, которые позволяют учащимся изучить интересную и насыщенную историю Крыма, его неповторимое природное богатство, уникальное культурное наследие народов Крым, особенности его экономического и политического развития, а также познакомится с современными экологическими и хозяйственными проблемами, а также перспективами процветания родного края.

«Любовь к родному краю, к родной культуре, к родному селу или городу, к родителям, к родной речи начинается с малого: с любви к своей семье, к своему жилищу, к своей школе, постепенно расширяясь, эта любовь к родному краю переходит к своей стране, к ее истории, ее прошлому и настоящему» Д.С. Лихачев.

Крымский полуостров небольшой по размерам, но какое сочетание природного разнообразия, сколько разных неожиданностей и загадок ждет нас 
на каждом шагу. Это огромный музей под открытым небом. И нам посчастливилось жить в этом чудесном уголке природы, который является для нас нашей малой Родиной - неотъемлемой частью Российской Федерации.

Благодаря курсу «Крымоведение» обучающиеся получают возможность шаг за шагом изучать Крым во всем его природном великолепии и культурноисторическом разнообразии.

Прикоснутся к прошлому, к древности можно с помощью археологии, основы которой изучаются на уроках крымоведения. Учащиеся нашей школы имеют возможность применять теоретические знания на практике. Во время летней практике ребята проводят раскопки и собирают информацию о стоянке первобытных людей находящейся в районе нашего села.

Знакомство с памятниками культуры, изучение истории родного края по конкретным археологическим источникам, обычаев и традиций народов, населяющих тот или иной регион, выявление связи местных культов и обрядов с особенностями истории края содействуют воспитанию мировоззрения детей и подростков. Историческое познание родного края раскрывает учащимся связи родного города, села с великой Родиной, помогает уяснить неразрывное единство истории, почувствовать причастность к ней каждой семьи и признать своим долгом, честью стать достойным наследником лучших традиций родного края.

Пробуждение начинается с обращения к истокам своего рода. Уроки крымоведения побуждают детей задуматься о своих корнях, о своих предках, составляя генеологическое древо своего рода, обучающиеся более полно знакомятся с историей своей семьи, с историей своего края, не только ради познания, но и ради сохранения прошлого. Разве может человек, знающий свою родословную, разрушить дом, который был построен его предками, который хранит тепло нескольких поколений. Разве может человек погубить дерево, которое было посажено его дедом или отцом. Разве может человек забыть свою землю обильно политой кровью ее защитников [1, стр. 4].

Крымчане всегда с честью отстаивали свободу и независимость своей Родины: в период борьбы с монголо-татарами, а особенно в годы Великой Отечественной войны. Уроки крымоведения дают прекрасную возможность воспитывать школьников на боевых, трудовых, культурных традициях. Примерами беззаветного служения Родине могут быть подвиги односельчан, героев войны, среди которых были и выпускники нашей школы. Желание учащихся больше узнать о выдающихся земляках, об истории своей школы 
побуждает их к поисковой, исследовательской, научной деятельности. Итогами поисковой работы стало пополнение информацией школьного музея, а также участие в различных конференциях, исследовательских конкурсах. Многие учащиеся нашей школы являются членами военно-патриотического клуба «Отечество», где ребята сами могут стать участниками боевых действий.

Природа края рассматривается как часть природы более крупных территорий - района, области, природной зоны, страны. Поэтому в процессе ее изучения важно определить черты, общие с природой более крупных регионов, что дает возможность опираться на личный опыт детей, их наблюдения, кругозоров. В то же время выявляются местная специфика природных компонентов и их территориальных сочетаний, типичные явления, характеризующие природу родного края, а также ее уникальные объекты и связанные с ними процессы.

Знакомство с окружающим ландшафтом, изучение действия законов, причинно-следственных связей природы формируют у детей интерес и склонность к исследовательской работе, которые в дальнейшем могут сыграть существенную роль в их профессиональном становлении.

Красота Крымского полуострова, ее особый природный дух многие поколения вдохновляют на творчество. Наша земля богата талантливыми людьми, которые оставили заметный вклад в различных областях культуры.

С Крымом связана, жизнь и творчество многих выдающихся земляков. Их имена, дела не канут в безвестность, так как на уроках крымоведения мы не только знакомим с биографией, творчеством, но и учим уважать, почитать своих земляков, которые внесли немалый вклад в развитие Отечественной науки, техники, военного искусства, литературы, культуры, спорта.

Краеведение в школе является результатом совместной деятельности ученика и учителя, носит творческий характер. Оно помогает воспитанию в душе у ребёнка с самого раннего возраста любви к родине, чувству красоты, формированию познавательного интереса, развитию способностей, эстетического вкуса, устойчивых нравственных принципов. Краеведение способствует выработке активной жизненной позиции учащихся, нацеливает их на общественно-полезную работу, прежде всего по охране, пропаганде памятников истории и культуры своей области, своего района, своего города.

Ни у кого не вызывает сомнений утверждение, что необходимое нашей стране возрождение духовности возможно только при условии глубочайшего 
изучения истории Российского государства и вместе с этим прошлого и настоящего своей малой родины [2, стр.40].

\section{Список литературы}

1. Данильченко Л. Чему учит история родного края / Л. Данильченко // Воспитание школьников. - № 6. - 2005.

2. Ермолаева Л. К. Изучение своего края: проблемы и подходы к их решению / Л. К. Ермолаева // Преподавание истории и обществознания в школе. - № 3. - 2002. -с.40-47.

3. Ляшенко Е.А. Школа юного краеведа / Е. А. Ляшенко. - Волгоград. 2007.

(C) О.А. Максименко, 2020 